\title{
Why Issues of Islamic Leadership are Important to ASEAN
}

\author{
Osman Bakar*
}

In Southeast Asia, it is only rarely that issues of Islamic leadership are seriously discussed at respectable forums organised by prominent organisations, even when these are Muslim-initiated or Muslim-led. This is quite a surprising thing - and an unfortunate one. Given the large Muslim presence in the region, one would expect to see the opposite picture as true. Therefore, when I was invited by the Asian Institute of Management (AIM) in Manila to deliver a keynote speech at its two-day conference in April 2010 on the theme of Islamic leadership in a changing ASEAN (Association of Southeast Asian Nations) I did not hesitate to accept. At last, I thought, there is a positive change of mindset in the region concerning the international role of Islamic leadership. AIM organised the regional conference in collaboration with the Institute of Islamic Understanding Malaysia (IKIM) and the Paramadina University in Jakarta.

In my address, I congratulated the organisers for having come forward with such a significant theme for the conference. I told them that many people will read the theme as a message of acknowledgement of the important role that Islam can play and the important contribution it can make towards the realisation of peace and development within ASEAN.

I would like to take up here one of the points that I had stressed in my keynote address. This pertains to why ASEAN has to be concerned with issues of Islamic leadership. In my view, there are at least three reasons for this regional concern. One is demographic, the second historical, and the other civilisational. Demographically, Muslims constitute about 40 per cent of the ASEAN population, making them its largest single religious group. In the light of this demographic factor alone, therefore, ASEAN Muslims can argue that they deserve to be considered as a major stakeholder in the regional community's future development and wellbeing. The second reason is the historically rooted conflicts in southern Thailand and in Mindanao, the Philippines - both are multi-dimensional in nature, but are also largely cultural. They have prevailed for a long time and have so far defied all peace initiatives. These conflicts can threaten peace and development in ASEAN. Since Islam and Muslims are part of those conflicts, ASEAN places hope on a more enlightened future Islamic leadership to find lasting solutions to the conflicts.

The third reason is the factor of Islam's civilisational richness that Muslims would like to share with the rest of the community. Islam claims to have at its disposal

* Professor Osman Bakar is the Deputy CEO of IAIS Malaysia. 
the 'intangible wealth' in the form of its universal and contemporaneous teachings that may be tapped for answers to many of the problems ASEAN and its member states are now facing As a living civilisation that is now in the fifteenth century of its existence, Islam also claims to have inherited a rich treasury of historical experiences that may offer to the world useful insights into some of the major issues with which it is currently confronted.

Let me mention five of these issues and challenges. First, there is the issue of knowledge society. This issue is becoming increasingly important in our contemporary global society. More and more people are talking, for example, about the need for a knowledge-economy (k-economy). In this new discourse, issues of knowledge and of knowledge-divide between societies feature prominently. The belief underlying this new thinking is that knowledge investment would be the key to future development and progress, particularly in the economic sphere. Just to illustrate the growing importance of these issues, IAIS Malaysia and The New Club of Paris, one of the world's leading think-tanks on the subject, organised on 16 June 2010 a public dialogue on the theme of 'value-based development' that was well received. The reason why IAIS, an Islamic think-tank, has been approached by various parties for collaborative programmes is because they are interested to know what Islam has to say about these engaging issues.

The second issue is that of tradition and modernity, which is related to the issue of change and permanence in human society. Every society faces this issue, more so developing ASEAN societies. In this region, as in other parts of the world, there have been approaches to economic development and social progress that tend to marginalise cultural traditions. Advanced countries in the West have long marginalised religious traditions as well in their path to development and progress. But in our region - more so among its Muslim communities - despite the rapid modernisation and development, many aspects of its religious and cultural traditions still thrive to this day. Reconciling between tradition and modernity is an on-going thing in the region. There is a large constituency out there in ASEAN societies who still believe in the importance of tradition and who insist on its continuing relevance. To the extent that religious and cultural traditions are still alive and strong in ASEAN, issues of tradition and modernity will continue to engage the minds of many people in the region. In Muslim societies in particular, given the pervasive influence of tradition, their encounter with modernity and modernisation has also generated ideas and movements for religious reforms. One of the most important religious reforms taking place in Muslim societies today is in the field of religious education. It is noteworthy that in the Philippines the 'ulama ' have organised themselves into a group, meeting regularly to discuss issues important to the Muslim minority community in the country such as reforms in the traditional madrasahs and the role of the 'ulamā'. 
The third issue is the challenge of globalisation and 'glocalisation'. People generally understand globalisation to mean that our contemporary world is characterised by greater flows of ideas and goods across national borders and increasing interdependence between member nations of the international community. If we view globalisation as an all-embracing phenomenon and as a total global process to embrace all kinds of ideas and goods - including the economic and financial, the political, the religious and cultural, and the scientific and technological - then we can see how impactful it has been on the lives of nations. The whole world has been impacted by globalisation, both positively and negatively. Southeast Asia is traditionally known as a region that is open to cultural influences from the outside world. Therefore, it is not at all surprising to see ASEAN receiving a more extensive impact of globalisation than many other regions of the world. The manifold challenges of globalisation are well-known. Muslim leaders in the region have responded to at least some of these challenges with varying degrees of success. But problems remain. Generally speaking, in response to the challenges of globalisation, Muslim leaders in ASEAN countries appear to be guided by the principle that the benefits of globalisation should be exploited to the fullest and its negative impact simultaneously minimised. When Malaysia's present Prime Minister, Dato' Sri Mohd Najib Tun Abdul Razak, was deputy Prime Minister he sought to popularise the idea of 'glocalisation' as a response to globalisation. 'Glocalisation' is presented as the guiding principle that would help a nation to define its national interests in the light of both the positive and negative impacts of globalisation.

The fourth issue is the challenge of cultural pluralism, which I understand in its broadest sense to include religious pluralism. ASEAN as a whole is well noted for its cultural pluralism. The Philippines is predominantly Catholic. Indonesia is the world's most populous Muslim nation. Thailand, Vietnam, and Myanmar are predominantly Buddhist. Moreover, there are many Hindus in Malaysia, Indonesia, and Singapore. Of all the regional groupings in the world today, ASEAN is easily the most heterogeneous. Some ASEAN countries are more pluralistic than others. In terms of its religious make-up, Malaysia is perhaps the most pluralistic of them all. Even before the post-colonial wave of globalisation the Southeast Asian region was already pluralistic. But globalisation has only made it more complex in its cultural make-up. Cultural pluralism poses numerous challenges that are not easy to overcome. It would indeed be a tremendous challenge for ASEAN to emerge as a fully integrated regional community given its unmatched cultural diversity. The experience of Muslim leaders in managing cultural pluralism in their respective countries may provide useful input into the regional discussion on the subject. Malaysia, in particular, has often been cited as a Muslim-majority country that has done relatively well in managing cultural pluralism and diversity. 
The fifth issue and a final one is the issue of sustainable development. As ASEAN becomes more developed in the sense conventionally understood, which means increasing depletion of its natural resources without replacement, the more it has to worry about its future resources and about the fate of its future generations. A new philosophy of development and a new approach to it is needed. Sustainable development is now presented as the most sensible alternative for the world to adopt. Muslim academics, scholars, intellectual and political leaders, and nongovernmental activists have all embraced the idea and, moreover, they have done so by claiming that it accords with the core teachings of Islam.

All of these issues are being addressed in the core teachings of Islam as embodied in the Qur'ân. Since these issues will become more engaging to the region in the years to come, and since these are at the same time of major concern to Islam, we can expect to see a more visible role by the Islamic leadership at both national and regional levels in addressing these issues. 